\title{
Development of Two Stages Cock's Semen Extender for Room Temperature Storage at Laboratory
}

\author{
Negassi Ameha, Ram P. Moudgal and Asefa Asmare \\ Department of Animal Science, Alemaya University, Alemaya, Ethiopia
}

\begin{abstract}
A simple cock's semen dilutor (two-stage) with minimum ingredients was developed in the present study. The stage-1dilutor was aimed to reduce the motility and metabolism during storage and the stage-2 dilutor was to be added just prior to insemination to revive the motility to facilitate the entry of spermatozoa into sperm host gland. Initially, the semen was diluted $1: 1$ with the stage-1 dilutor having lower $\mathrm{pH}$ that reduced the motility and metabolism. Subsequently, after $24 \mathrm{~h}$, the diluted semen was mixed slowly with another dilutor stage- 2 at $1: 2$ ratios to revive the motility of the spermatozoa to normal level. Phosphate buffer was the base for both storage (stage-1) and recovery (stage-2) dilutors with a $\mathrm{pH}$ of 6.5 and 7.5 , respectively. In stage-1 dilutor sodium glutamate to minimize metabolism of spermatozoa and antibiotics to check bacterial growth were used whereas these were absent in stage-2 dilutor. Glucose was added as energy source in the dilutor of both stages. The osmolarity of stage- 1 and stage- 2 dilutors was 346 and $327 \mathrm{Osm} / \mathrm{kg} \mathrm{H}_{2} 0$, respectively. This dilutor can be used to store the cock's semen at room temperature $\left(17-21^{\circ} \mathrm{C}\right)$ for $24 \mathrm{~h}$ with sustained motility. This new approach for two-stage dilutor of cock's semen storage at room temperature for extended period could be a useful A.I. tool under farm condition.
\end{abstract}

Key words : cock, motility, osmolarity, semen, two-stage dilutor

J. Poult. Sci., 44 : 78-84, 2007

\section{Introduction}

Artificial insemination (AI) technology is one of the important managemental tools for the successful poultry industry. It has several uses and a few limitations (Lake, 1967 ; Lake, 1983 ; Lake, 1989 ; Surai and Wishart, 1996 ; Wishart et al., 2001 ; Getnet et al., 2003). Semen dilution is one of the most critical components of AI technology (Schindler et al., 1955). Several suitable semen dilutors are reviewed for low temperature storage up to around 48 hours (Etches, 1996). The chicken semen dilutors available so far have complex composition and require many ingredients ; they are also difficult to prepare at farm level (Lake, 1967 ; Lake, 1983). These dilutors can keep the spermatozoa viable at lower temperatures for reasonably long periods by suppressing the activities of sperm temporarily. It is well known that the reduced motility and metabolism extend the life of spermatozoa but the motility is required for their entry in sperm host gland (Haris et al., 1961 ; Lake, 1983 ; Bootwalla and Miles, 1992). Therefore, it is difficult to extend the life of the spermatozoa by adding an ingredient that suppresses the motility in a single dilutor. If added, it has to be removed before insemination that may not always possible at farm level. This has prompted to develop a dilutor for room temperature with two-stage dilution wherein ; the life of the spermatozoa is prolonged at first stage through reduced metabolism followed by the addition of second stage dilutor just before insemination for reviving the

Received : June 5, 2006, Accepted : August 22, 2006

Correspondence to : Dr. R.P. Moudgal, Division of Physiology and Reproduction, Central Avian Research Institute Izatngar-243122, India

Tel : +91-0581-2301220 Fax : +91-0581-2301321 E-mail : rpmoudgal@yahoo.com 
motility.

In turkey, increased $\mathrm{pH}$ of dilutor induced higher respiration rates of spermatozoa in vitro (Pinto et al., 1984). The metabolism and motility of spermatozoa remained lower towards acidic $\mathrm{pH}$ (Pinto et al., 1985). Sodium glutamate normally presents in cock semen in sufficient quantity and also reduced the motility at higher levels (Macpherson et al., 1977 ; Howarth, 1983). This reduction in metabolism and motility of spermatozoa is suppressed by $\mathrm{Ca}^{++}$ chelation (Thompson and Wishart, 1988). Keeping this in view, the ingredients for the two-stage dilutor were chosen. To the best of our knowledge, it is the first attempt to develop a dilutor for room temperature with two-tier dilution. The two components of the dilutor (Stage-1 and Stage-2) meet the opposite objectives at two stages of dilution. Initially just after semen collection, addition of stage-1 dilutor suppresses metabolism of spermatozoa and before insemination dilution with stage-2 dilutor recover the motility. This helps in prolonging the fertile life of cock's spermatozoa at room temperature.

\section{Materials and Methods}

\section{Birds}

Healthy adult Rhode Island Red males were used for the present study. These birds were kept under standard management practices. Water and feed was given ad libitum. Semen was collected from individually caged cocks by abdominal massage (Burrows and Quinn, 1934).The cocks yielding good quality of semen were retained for this study. The cocks giving frequently contaminated semen were excluded. The cocks yielding $0.5 \mathrm{ml}$ or more volume of semen per ejaculate, possessing subjective motility rating in fresh semen of the upper two categories out of 0-5 scale (Allen and Champian, 1955) and sperm concentration above $10^{9}$ per $\mathrm{m} l$ (counted by haemocytometer) of ejaculate were considered for further experimentation.

Optimization of pH of Phosphate Buffers for Stage-1 and Stage-2 Dilutor

For developing phase-1 (storage) dilutor, initially three $\mathrm{pH}(6.0,6.5$ and 7.0) combinations of phosphate buffer were tried, and then for phase-2 (recovery of motility) dilutors two $\mathrm{pH}$ (7.0 and 7.5) phosphate buffers were assessed. For making phosphate buffer with different $\mathrm{pH}$ two salts $\left(\mathrm{K}_{2} \mathrm{HPO}_{4}\right.$ and $\mathrm{KH}_{2} \mathrm{PO}_{4}$ ) were considered. The change in ratio of these two phosphate salts resulted into alteration in $\mathrm{pH}$. In order to maintain the similar osmolarity of different $\mathrm{pH}$ solutions, these salts were dissolved separately at a concentration in such a manner so that the osmolarity of each solution remained same $(300 \mathrm{mOsm})$. This helped in maintaining the uniform osmolarity in all the $\mathrm{pH}$ solutions. The $\mathrm{pH}$ of different buffers used in the present study was measured by a digital $\mathrm{pH}$ meter. The osmolarity of different solutions was measured through freezing point osmometer. The exact amount required of these two salts to obtain different solutions of the desired $\mathrm{pH}$ and osmolarity are available under following respective stage- 1 and stage- 2 phosphate buffers. Optimization of Stage-1 (storage) Phosphate Buffers

The optimum physiological osmolarity of the buffers was considered as $300 \mathrm{mOsm}$. The solutions of $\mathrm{K}_{2} \mathrm{HPO}_{4}(22.5 \mathrm{~g} / \mathrm{L})$ and $\mathrm{KH}_{2} \mathrm{PO}_{4}(24.4 \mathrm{~g} / \mathrm{L})$ were prepared with same osmolarity. These two solutions were mixed separately in different proportion to achieve $\mathrm{pH}$ of $6.0,6.5$ and 7.0 with same osmolarity. To obtain pH 6.0 phosphate buffer, 25 $\mathrm{m} l \mathrm{~K}_{2} \mathrm{HPO}_{4}$ and $100 \mathrm{~m} l \mathrm{KH}_{2} \mathrm{PO}_{4}$ were mixed up. Likewise for $\mathrm{pH} 6.5$ level, $55 \mathrm{ml}$ of $\mathrm{K}_{2} \mathrm{HPO}_{4}$ and 100 $\mathrm{m} l$ of $\mathrm{KH}_{2} \mathrm{PO}_{4}$ were added together. For the preparation of $\mathrm{pH} 7.0$ buffer, $230 \mathrm{~m} l$ of $\mathrm{K}_{2} \mathrm{HPO}_{4}$ and 100 $\mathrm{ml}$ of $\mathrm{KH}_{2} \mathrm{PO}_{4}$ were mixed. The osmolarity in all the foregoing groups was observed around $300 \mathrm{mOsm}$ using osmometer. These buffers were stored at $4{ }^{\circ} \mathrm{C}$ in a refrigerator.

Optimization of Stage-2 (to recover motility) Phosphate Buffer

To prepare the $\mathrm{pH} 7.0$ buffer with $300 \mathrm{mOsm}$, these buffer ingredients from above said solutions $\left(230 \mathrm{ml}\right.$ of $\mathrm{K}_{2} \mathrm{HPO}_{4}$ and $100 \mathrm{~m} l$ of $\left.\mathrm{KH}_{2} \mathrm{PO}_{4}\right)$ were mixed up. For pH 7.5 buffer, $330 \mathrm{ml}$ of $\mathrm{K}_{2} \mathrm{HPO}_{4}$ and $50 \mathrm{ml}$ of $\mathrm{KH}_{2} \mathrm{PO}_{4}$ were added up. Besides, glucose was also added $(0.5 \%)$ to meet energy requirement of spermatozoa.

\section{Evaluation of the Semen with $\mathrm{pH}$ and Time}

The semen (pooled) was diluted with one part of the each phase-1 phosphate buffer $(\mathrm{pH} 6.0,6.5$ or 7.0). For each level, six replications were used. The semen was stored at room temperature $\left(17-21^{\circ} \mathrm{C}\right)$ for different time periods. The motility and live and dead counts of the spermatozoa were monitored continuously. The best $\mathrm{pH}$ for the storage was determined where a sustained progressive forward motility of spermatozoa was not less than $60 \%$ and, 
dead and abnormal spermatozoa together were not more than $20 \%$.

For estimating the percent progressive forward motility, a drop of diluted semen was put over the slide and covered with cover slip taking all routine precautions. The spermatozoa were observed under high power objective microscope. Under each field, the easily accessible spermatozoa were viewed and recorded. Within the field the numbers of spermatozoa possessing forward motility in that area were counted. On percent basis the spermatozoa possessing forward progressive motility were determined.

For the evaluation of percent dead and abnormal spermatozoa, a routine staining procedure using eosin and negrosin was followed (Cooper and Rowell 1958). On staining around 200 spermatozoa were viewed under oil immersion objective and the proportion of dead and abnormal spermatozoa were recorded (Allen and Champian, 1955). These parameters were handled as indicated recently (Zelleke et al., 2005).

The stored semen in stage-1 dilutor $(1: 1)$ was mixed with stage-2 diluter (one part semen stored in storage buffer with two part phase-2 recovery buffer), separately for $\mathrm{pH} 7.0$ or 7.5. The motility was estimated at the end of storage period and immediately after mixing up the phase- 2 dilutor at all steps. The best combination, which retains the spermatozoa in good condition with respect to motility and livability as indicated above for maximum period was selected for further study.

\section{Fortification of Phosphate Buffer with Sodium Gluta- mate}

The sodium glutamate was added at 25 and 50 percent to the best stage- 1 buffer ( $\mathrm{pH}$ 6.5) by keeping the same osmolarity. Only sodium glutamate with similar osmolarity was used as control. $28.8 \mathrm{~g}$ of sodium glutamate was dissolved in one liter of distilled $\mathrm{H}_{2} \mathrm{O}$ to achieve $300 \mathrm{mOsm}$ on estimation. The semen was diluted with these dilutors and was evaluated as described previously.

\section{Fortification of Stage-1 Dilutor with Energy Source}

Glucose was used as primary energy source in both stage- 1 and stage- 2 dilutors in the present study. Glucose was added indifferent proportions i.e. $0.6 \%$, $2.8 \%$ and $5 \%$ to the best of buffer and glutamate combination. The estimated osmolarity of these solutions is mentioned in Table 1. Penicillin and streptomycin were added to the best composition to
Table 1. The osmolarity of final phase-1 semen extender as estimated with different glucose level

\begin{tabular}{cc}
\hline \hline $\begin{array}{c}\text { Final stage-1 semen extender with } \\
\text { different glucose levels }\end{array}$ & $\begin{array}{c}\text { Osmolarity measure } \\
(\mathrm{mOsm})\end{array}$ \\
\hline $0.6 \%$ & 346 \\
$2.8 \%$ & 452 \\
$5.0 \%$ & 583 \\
\hline
\end{tabular}

prevent microbial growth on longer storage of semen in media as prescribed elsewhere (Etches, 1996).

\section{Statistical Analysis}

Percentage data were transformed by using arcsine and the standard CRD procedure were used to test the statistical difference. The selected storage time and $\mathrm{pH}$ diluter combination were analysed by using MSTATC and the mean difference was analysed using LSD test.

\section{Results}

\section{Buffer pH for Semen Extenders}

The results of different Stage-1 storage buffer $(\mathrm{pH}$ 6.0, 6.5 and 7.0) after adding recovery buffer $(\mathrm{pH}$ 7.0 or 7.5 ) on motility and percent dead spermatozoa including abnormal are presented in Table 2 . The longest period of semen storage under this treatment was observed as $10 \mathrm{~h}$ to sustain the desired level of motility $(\geq 60 \%)$ and percentage of dead and abnormal spermatozoa $(\leq 20 \%)$. Lowest percent dead spermatozoa including abnormal and maximum motility were obtained in the combination of storage buffer $\mathrm{pH} 6.5$ and recovery buffer $\mathrm{pH}$ 7.5.

From Table 2 within storage buffer comparison (pH 6.0, 6.5, and 7.0), no significant difference was noticed after $10 \mathrm{~h}$ on motility by statistical analysis, however numerically at $\mathrm{pH} 6.5$ the motility was highest. However, significant improvement was noticed in motility with the addition of recovery buffer $(\mathrm{pH}$ 7.5) to the storage buffer ( $\mathrm{pH} 6.0$ and 6.5). However, using storage buffers $(\mathrm{pH} 7.0)$ there was no statistical difference on adding the recovery buffers.

The results on percent dead including abnormal spermatozoa varied significantly between $\mathrm{pH} 6.0$ and 7.0 storage buffers however at $\mathrm{pH} 6.5$, the mean value on this parameter was in between $\mathrm{pH} 6.0$ and 7.0 and this value did not differ significantly from either of these two $\mathrm{pH}$ buffers (Table 2). Considering the fixed motility and percent dead including abnormal spermatozoa criteria, the grouping of $\mathrm{pH}$ 6.5 of phosphate buffer for storage of semen and $\mathrm{pH}$ 
Table 2. Effect of storage and recovery buffers of different $\mathbf{p H}$ for $10 \mathrm{~h}$ semen storage at room temperature $\left(17-21^{\circ} \mathrm{C}\right)$ on motility and percent dead plus abnormal spermatozoa (transformed mean $\pm \mathrm{SE}$ )

\begin{tabular}{|c|c|c|c|c|}
\hline \multirow{3}{*}{$\begin{array}{c}\text { Storage buffer } \\
\text { pH }\end{array}$} & \multirow{3}{*}{$\begin{array}{c}\% \text { dead } \\
\text { including } \\
\text { abnormal } \\
\text { spermatozoa }\end{array}$} & \multicolumn{3}{|c|}{ (\% motility of spermatozoa } \\
\hline & & \multirow{2}{*}{$\begin{array}{c}\text { Storage buffer } \\
\text { Control* }^{*}\end{array}$} & \multicolumn{2}{|c|}{ Recovery buffer } \\
\hline & & & $\mathrm{pH} 7.0^{* *}$ & $\mathrm{pH} 7.5^{* *}$ \\
\hline 6.0 & $\begin{array}{c}23.323 \pm 1.44^{\mathrm{a}} \\
(15.8) * * *\end{array}$ & $\begin{array}{c}40.133 \pm 10.22^{\mathrm{d}} \\
(43.3)\end{array}$ & $\begin{array}{c}48.383 \pm 2.01^{\mathrm{bcd}} \\
(55.8)\end{array}$ & $\begin{array}{c}53.767 \pm 1.83^{\mathrm{ab}} \\
(65.0)\end{array}$ \\
\hline 6.5 & $\begin{array}{c}20.660 \pm 1.66^{\mathrm{ab}} \\
(12.6)\end{array}$ & $\begin{array}{c}45.317 \pm 7.68^{\mathrm{bcd}} \\
(50.8)\end{array}$ & $\begin{array}{c}51.300 \pm 2.14^{\mathrm{abc}} \\
(67.5)\end{array}$ & $\begin{array}{c}58.017 \pm 3.33^{\mathrm{a}} \\
(71.6)\end{array}$ \\
\hline 7.0 & $\begin{array}{c}19.130 \pm 0.98^{\mathrm{b}} \\
(10.8)\end{array}$ & $\begin{array}{c}42.900 \pm 6.8^{\mathrm{cd}} \\
(50.0)\end{array}$ & $\begin{array}{c}50.317 \pm 3.96^{\mathrm{abc}} \\
(59.2)\end{array}$ & $\begin{array}{c}50.350 \pm 3.65^{\mathrm{abc}} \\
(59.2)\end{array}$ \\
\hline
\end{tabular}

Note : The transformed mean values of each trait with different superscript differed significantly ( $p$ $<0.05)$.

* One part of semen added to one part of storage buffer before the start of storage.

** One part storage buffer bearing semen diluted at the end of storage with two part of recovery buffer.

*** The values in the parenthesis are the means of original values.

Table 3. Effect of substituting sodium glutamate to storage buffer (pH 6.5) by maintaining same pH and osmolarity for cock semen storage $(20 \mathrm{~h})$ on motility and percent dead spermatozoa at room temperature (transformed mean $\pm \mathrm{SE}$ )

\begin{tabular}{|c|c|c|c|}
\hline \multirow{2}{*}{$\begin{array}{l}\text { Sodium glutamate } \\
\text { replacement for } \\
\mathrm{K}_{2} \mathrm{HPO}_{4} \text { and } \\
\mathrm{KH}_{2} \mathrm{PO}_{4}\end{array}$} & \multirow{2}{*}{$\begin{array}{l}\% \text { dead sperm } \\
\text { including abnormal } \\
\text { at the end in } \\
\text { storage buffer }\end{array}$} & \multicolumn{2}{|c|}{$\begin{array}{l}\% \text { motility of spermatozoa } \\
\text { at the end of storage }\end{array}$} \\
\hline & & $\begin{array}{l}\text { Storage buffer } \\
(\mathrm{pH} 6.5)^{*}\end{array}$ & $\begin{array}{c}\text { Recovery buffer } \\
(\mathrm{pH} 7.5)^{* *}\end{array}$ \\
\hline $25 \%$ & $\begin{array}{r}24.965 \pm 0.83^{c} \\
\quad(17.83) * * *\end{array}$ & $\begin{array}{c}27.450 \pm 4.96^{\mathrm{b}} \\
(22.50)\end{array}$ & $\begin{array}{c}50.800 \pm 1.82^{\mathrm{a}} \\
(60.00)\end{array}$ \\
\hline $50 \%$ & $\begin{array}{c}34.428 \pm 5.59^{b} \\
\quad(32.50)\end{array}$ & $\begin{array}{c}14.850 \pm 1.41^{\mathrm{c}} \\
(7.00)\end{array}$ & $\begin{array}{c}27.533 \pm 2.79^{b} \\
\quad(21.70)\end{array}$ \\
\hline $100 \%$ & $\begin{array}{l}39.837 \pm 3.56^{\mathrm{a}} \\
\quad(41.17)\end{array}$ & $\begin{array}{c}11.533 \pm 1.69^{c} \\
(4.66)\end{array}$ & $\begin{array}{c}14.683 \pm 1.45^{\mathrm{c}} \\
(21.70)\end{array}$ \\
\hline
\end{tabular}

Note: The transformed mean values with different superscript differed significantly $(p<0.05)$ within each trait.

* One part semen added to one part of storage buffer before the start of storage.

** One part storage buffer bearing semen diluted at the end of storage with two part of recovery buffer.

*** The values in the parenthesis are the original values.

7.5 for recovery of motility before insemination was selected for further study.

\section{Fortification of Buffer with Sodium Glutamate}

The detail results on substituting sodium glutamate at different levels to selected storage buffer $(\mathrm{pH}$ 6.5) are presented in Table 3. The longest period of semen storage as per stipulated target using different sodium glutamate levels was found $20 \mathrm{~h}$. Besides, all the storage media groups resulted into lower motility as compared to their respective recovery buffer groups. Percent dead including abnormal spermatozoa showed significant difference among the three sodium glutamate levels (Table 3 ). Based on these observations $25 \%$ sodium glutamate was chosen for further study.

\section{Fortification of Best Stage-2 Dilutor with Glucose}

The results on supplementing different concentrations of glucose are given in Table 4. The longest period of semen storage after adding glucose to the storage media was recorded as $24 \mathrm{~h}$ considering 


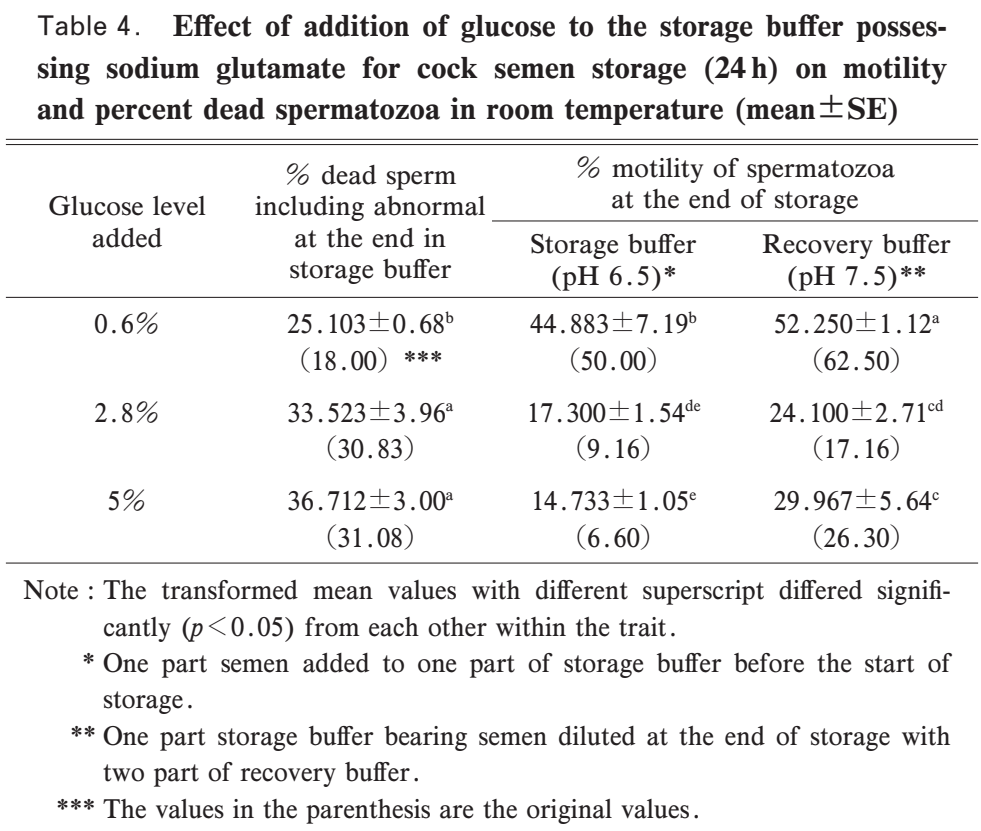

targeted level of motility and mortality of spermatozoa including abnormal. At $0.6 \%$ level of glucose in both of the storage and recovery buffers the motility was noted significantly $(p \leq 0.05)$ superior to other two levels of glucose and also a significant improvement was recorded on adding recovery buffer to the storage buffer (Table 4). At storage buffer with $2.8 \%$ or $5 \%$ of glucose levels, the motility on adding recovery buffer did not arrive at stipulated level of motility ( $\geq 60 \%$ ).

The percent dead including abnormal spermatozoa was significantly $(p<0.05)$ lower at $0.6 \%$ level of glucose when compared to other two higher levels (Table 4). Therefore, glucose at $0.6 \%$ level was identified as the best. Antibiotics were supplemented to the final composition to control the microbial population as per standard recommendations (Etches, 1996). The complete final compositions of storage and recovery dilutors to store the cock's semen at room temperature are available in Table 5.

\section{Discussion}

A comparative sketch on motility between storage and recovery groups with best-selected combinations at different levels of standardization are summarized in Table 6. At all steps apparent improvement in motility was obtained with the addition of recovery buffers to the storage buffers. At every additional step (step-1, optimised $\mathrm{pH}$; step-2,
Table 5. Composition of two-stage dilutor developed for room temperature

\begin{tabular}{llcc}
\hline \hline \multicolumn{1}{c}{ Ingredients } & \multicolumn{2}{c}{ Room temperature } \\
\cline { 3 - 4 } & & $\begin{array}{c}\text { For storage } \\
\text { (phase-1) }\end{array}$ & $\begin{array}{c}\text { For recovery } \\
\text { (phase-2) }\end{array}$ \\
\hline 1 & $\mathrm{~K}_{2} \mathrm{HPO}_{4}(\mathrm{~g})$ & 7.71 & 19.37 \\
2 & $\mathrm{KH}_{2} \mathrm{PO}_{4}(\mathrm{~g})$ & 9.94 & 3.21 \\
3 & Sodium glutamate $(\mathrm{g})$ & 7.2 & - \\
4 & Glucose $(\mathrm{g})$ & 6.0 & 5.0 \\
5 & Antibiotic mix $(\mathrm{ml}) *$ & 2.0 & - \\
6 & pH & 6.5 & 7.5 \\
7 & Total volume $(\mathrm{ml})$ & 1000 & 1000 \\
8 & Osmolarity $\left(\mathrm{mOsm} / \mathrm{kg} \mathrm{H} \mathrm{H}_{2} \mathrm{O}\right)$ & 346 & 327 \\
\hline
\end{tabular}

* $300 \mathrm{mg}$ of penicillin and $250 \mathrm{mg}$ of streptomycin dissolved in 5 $\mathrm{m} l$ of distilled water.

sodium glutamate fortification ; and step-3, on glucose supplementation), the time of semen storage increased from 10, 20 and to $24 \mathrm{~h}$ in successive steps at room temperature.

Step-1 The motility $(>60 \%)$ and percent dead including abnormal spermatozoa $(<20 \%)$ criteria for retaining the semen quality was sustained for 10 $\mathrm{h}$ storage duration at best $\mathrm{pH}$ buffer (Table 2). The best compatible result was obtained by using $\mathrm{pH} 6.5$ of storage buffer and $\mathrm{pH} 7.5$ of recovery buffer. This combination was picked up in a view of the following facts :

a) At $\mathrm{pH} 7.0$ of storage buffer the motility results were lower than $60 \%$ and since this was one of the qualifying cut off point and hence this $\mathrm{pH}$ 


\begin{tabular}{|c|c|c|c|c|}
\hline Steps* & $\begin{array}{c}\text { Ingredients for stage }-1 \\
\text { extender } \\
\text { (semen storage) }\end{array}$ & $\begin{array}{l}\text { Storage } \\
\text { time } \\
\text { (h) }\end{array}$ & $\begin{array}{l}\% \text { motility in } \\
\text { storage buffer } \\
(\mathrm{pH} 6.5)\end{array}$ & $\begin{array}{c}\% \text { motility on } \\
\text { adding stage- } 2 \\
\text { (recovery extender } ; \mathrm{pH} 7.5 \text { ) }\end{array}$ \\
\hline Step-1 & Buffer $\left(\mathrm{K}_{2} \mathrm{HPO}_{4}+\mathrm{KH}_{2} \mathrm{PO}_{4}\right)$ & 10 & $\begin{array}{c}51.300^{\mathrm{a}} \\
(67.50)^{* *}\end{array}$ & $\begin{array}{l}58.017^{\mathrm{a}} \\
(71.60)\end{array}$ \\
\hline Step-2 & Buffer with sodium glutamate & 20 & $\begin{array}{l}27.450^{\mathrm{b}} \\
(22.50)\end{array}$ & $\begin{array}{l}50.800^{\mathrm{a}} \\
(60.00)\end{array}$ \\
\hline Step-3 & $\begin{array}{l}\text { Buffer with sodium glutamate } \\
\text { and glucose }\end{array}$ & 24 & $\begin{array}{l}44.883^{\mathrm{b}} \\
(50.00)\end{array}$ & $\begin{array}{l}52.250^{\mathrm{a}} \\
(62.50)\end{array}$ \\
\hline
\end{tabular}

* The mean values with different superscripts within step-1, step -2 or step-3 varied signi-ficantly $(p<$ $0.05)$.

** The values in the parenthesis are the original values.

combination group was excluded.

b) Overall, only three combinations qualified the laid down criteria ( $\mathrm{pH} 6.0$ storage buffer with $\mathrm{pH} 7.5$ recovery buffers and $\mathrm{pH} 6.5$ storage buffer with both $\mathrm{pH} 7.0$ and 7.5 recovery buffer).

c) Though these three combinations did not vary significantly $(p>0.05)$ among themselves but numerically, $\mathrm{pH} 6.5$ storage buffer followed by $\mathrm{pH}$ 7.5 recovery buffer gave apparently superior results over the other two combinations.

d) Besides, at $\mathrm{pH} 6.5$ storage buffer the percent dead spermatozoa also remained lower than that of storage buffer with $\mathrm{pH}$ 6.0.

The motility of spermatozoa in storage buffer of $\mathrm{pH}$ 6.5 increased significantly $(p<0.05)$ on adding recovery buffer of $\mathrm{pH}$ 7.5. This observation supports the objective of taking up the buffer at lower $\mathrm{pH}$ for storage purpose and higher $\mathrm{pH}$ of recovery buffer to increase the motility for facilitating the entry of spermatozoa in the sperm host glands of female reproductive tract. These findings are also supported by Sexton and Giesen (1982), Howarth (1983), Bootwala and Miles (1992), who reported that the low $\mathrm{pH}$ reduces motility/metabolism. Further, for the entry of spermatozoa into sperm host gland, the livability and motility of spermatozoa are necessary (Haris et al., 1961 ; Bootwala and Miles, 1992) and the $\mathrm{pH}$ increase towards alkaline side picks up the metabolism (Pinto et al., 1984).

Step-2 The required motility and percent dead including abnormal sperm prevailed for $20 \mathrm{~h}$ on substituting $25 \%$ sodium glutamate to the best selected buffer at step-1 on keeping similar $\mathrm{pH}$ and osmolarity. This group gave significantly $(p<0.05)$ superior results and qualified the minimum laid down criteria in terms of motility and percent dead including abnormal spermatozoa.

Further sodium glutamate supplementation to the buffer enhanced significantly $(p \leq 0.05)$ more difference gap of motility at the end of storage and on recovery (Table 6). It is therefore, concluded that sodium glutamate reduces the motility and thereby it can serve useful purposes for storage purposes. This view also receives support in the earlier published work (Macpherson et al., 1977 ; Howarth, 1983). Thomson and Wishart (1988) further reported that sodium glutamate reduces the metabolism and motility of spermatozoa by chelating $\mathrm{Ca}^{++}$as calcium is required for acquiring the motility. The presence of sodium glutamate in storage buffers kept the motility lower and on adding recovery buffer improved the motility to the cut off level $(\geq 60 \%)$. Thus, the new objective considered under the present study to develop two stages diluents has shown reasonable way to extend the life of spermatozoa at room temperature.

Step-3 Further with the addition of glucose to the step- 2 best combination, the motility and percent dead including abnormal sperm criteria could be achieved up to the storage time of $24 \mathrm{~h}$. For further fortification of step- 2 best combination with $0.6 \%$ glucose was selected as it yielded significantly $(p<$ $0.05)$ more motility and lower percent dead including abnormal spermatozoa as compared to other groups (Table 4). At step-3 on adding glucose the difference in motility of spermatozoa between the stage- 1 and stage- 2 sustained significantly more but apparently this difference was higher at step-2 
(Table 6). It is but natural as glucose stimulates the metabolism and motility (Howarth, 1983 ; Lake, 1989).

Over all the room temperature semen extender developed under laboratory conditions meets the basic requirements as phase- 1 sustains the lower motility and on adding phase- 2 dilutor the motility could be enhanced to the desired level. However, to confirm or contradict the present finding such approaches of combination of two dilutors (one for storage and another for recovery) at room temperature could not be obtain from the published literature. However, several workers reported the opposite need, lower motility for storage of semen and relatively more motility at insemination in birds (Haris et al., 1961 ; Lake, 1983 ; Bootwala and Miles, 1992).

It can be concluded that the use of separate semen dilutor for storage purpose to minimize the motility and another dilutor to regain the motility prior to insemination has opened the scope for room temperature semen storage technology under tropical environment.

\section{Acknowledgments}

The authors acknowledge Dr K.V.H. Sastry, CARI, Izatnagar-243122, India for editorial screening of the MS.

\section{References}

Allen CJ and Champion LR. Competitive fertilization in fowl. Poultry Science, 34 : 1332-1342. 1955.

Bootwalla SM and Miles RD. Development of diluents for domestic fowl semen. World's Poultry Science Journal, $48: 121-128.1992$.

Burrow WH and Quinn JP. The collection of spermatozoa from the domestic fowl and turkey. Poultry Science, 16 : 19-24.1934.

Etches RJ. Artificial Insemination. In : Reproduction in Poultry (Etches RJ ed.) pp. 234-262. CAB International, Wellingford, Oxoen UK. 1996.

Getnet Z, Moudgal RP and Asefa A. Effect of semen quality and artificial insemination (AI) on fertility and hatchability of Rhode Island Red (RIR) breed of chick- en. Proc. $11^{\text {th }}$. Ethiopian Society for Animal Production (ESAP), Addis Ababa, Ethiopia. pp. 241-249. 2003.

Haris GC, Wilocox Jr FH and Shaffner CS. The storage of chicken and turkey spermatozoa by inhibition with 2 -ethyl-5-methylbenzamidazol (EBM). Poultry Science, $40: 777-781.1961$.

Howarth B JR. Comparison of diluents for holding cock semen six hours at $41^{\circ} \mathrm{C}$. Poultry Science, 62 : 10841087. 1983.

Lake PE. Artificial insemination in poultry and the storage of semen. World's Poultry Science Journal, 23 : 111-132. 1967.

Lake PE. Factors affecting the fertility level in poultry, with special reference to artificial insemination. World's Poultry Science Journal, 39 : 106-117. 1983.

Lake PE. Recent progress in poultry reproduction. World's Poultry Science Journal, 45 : 53-59. 1989.

Macpherson JW, Fiser PS and Reinhart BS. The effect of caproic acid, handling technique and storage times on the fertility of fowl spermatozoa. Poultry Science, 56 : 1334-1336. 1977.

Pinto O, Amir D, Schindler $\mathrm{H}$ and Hurwitz S. Effect of $\mathrm{pH}$ on the metabolism and fertility of turkey spermatozoa. Journal of Reproduction and Fertility, $70: 437-442$. 1984.

Pinto O, Amir D, Schindler H and Hurwitz S. Fertility of fresh and stored turkey spermatozoa in the presence or absence of glucose or fructose in the suspension medium. Poultry Science, 64 : 1388-1390. 1985.

Schindler H, Weinstein S, Moses E and Gabriel I. The effect of various dilutors and storage times on the fertilizing capacity of cock semen. Poultry Science, 34 : 11131117. 1955.

Sexton TJ and Giesen E F. Beltsville poultry semen extenderholding turkey semen for six hours at $15^{\circ} \mathrm{C}$. Poultry Science, 61 : 1202-1208. 1982.

Surai PE and Wishart GH. Poultry artificial technology in the countries of former USSR. World's Poultry Science Journal, $52:$ 27-40. 1996.

Thompson MF and Wishart GJ. Elucidation of the mechanism responsible for the temperature dependent reversible inactivation of the motility of fowl spermatozoa. British Poultry Science, 30 : 687-692. 1988.

Wishart GH, Stains HJ and Hazary RC. Evaluation of fertility : biological basis and practical applications. World's Poultry Science Journal, 57 : 309-314. 2001.

Zelleke G, Moudgal RP and Asmera A. Fertility and hatchability in RIR and WL as functionally modified by crossing them in alternate sex combinations (Gallus domestics). British Poultry Science, 46 : 119-123. 2005. 